\title{
KULIT OIL PULL UP UNTUK ATASAN
}

Oleh : Sutarti Rahayu, Imam Suyudi, Subandriyo

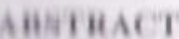

Whit with h was conducted to get the standard condition data of leather quality of oil pull up ifi wifiet thies. Nine samples oil pull up leather were used in this research, bought from the (tiiliti fin fury at Central Java, East Java, and Jakarta. The test of leather were done at Testing Ii hininy fur I eathers Comodity and Shoes, cover of physical test. The test result of the data

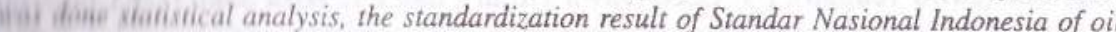
Wili wiil liathet for upper shoes can published after fixed on discussing on consensus meeting.

\section{INIISARI}

Iiilitil penelifian ini adalah untuk memperoleh data persyaratan standar mutu kulit oil-pullwi whanai data untuk penyusunan rancangan Standar Nasional Indonesia Kulit Oil-pull-up wiinh wistan sepatu. Penelitian ini menggunakan 9 sample kulit oil-pull-up yang berasal dar Whithinan kulit di Jawa Tengah, Jawa Timur, dan DKI Jakarta. Pengujian dilakukan di I Hiwninisum Uji Komoditi Kulit dan Sepatu (LUKKUS) yang meliputi uji fisis, uji kimiawi hith ill arganoleptis dengan mengacu pada SNI kulit boks. Kulit oil-pull-up yang memenuhi 14thithien standar dalam penelitian ini dapat digunakan untuk bahan baku atasan sepatu win whip lvaik karena mempunyai penampilan yang menarik yaitu bila ditekan/ditarik akan

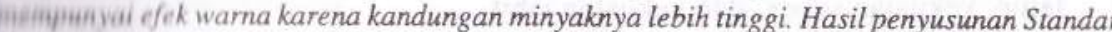
Vistimail Indonesia Kulit Oil-Pull-Up untuk atasan sepatu akan diterbitkan setelah ditentukan Whini pembahasan pada rapat konsensus sebagai Standar Nasional.

\section{"INDAIIULUAN}

Kebutuhan akan sepatu saat ini semakin meningkat, seiring dengan kebutuhan Hituelut meningkat pula kebutuhan akan bahan baku kulit untuk atasan sepatu.

Pada saat ini di pasaran banyak sekali dijumpai berbagai jenis/tipe kulit atavih sepatu. Salah satu jenis/tipe kulit atasan yang digemari konsumen adalah kulit wil mull up dari kulit sapi. Kulit Oil-Pull-Up dapat dibuat dari kulit dengan rajah inli utau rajah buatan (Corrected Grain). Kulit Oil-Pull-Up ini mempunyai keistimewaan antara lain efek warnanya yang spesifik dan relatif lebih tahan air. Oleh ar na produk tersebut sangat perlu membutuhkan jaminan mutu bahan baku kuli ii I will-Up, maka perlu disusun mengenai standar mutu kulit Oil-Pull-Up. Hal in. whinat penting untuk kesinambungan dan memantapkan pemasaran jenis men's lieu kulit Oil-Pull-Up merupakan salah satu pilihan untuk bahan atasan sepatu vain herpenampilan menarik (Ir. Widari, 1991/1992) dan mempunyai nilai tambah wala sepatunya khususnya men's shoes yang sedang digemari oleh konsumen. 
Untuk memperoleh efek Oil-Pull-Up yang baik, maka proses pengolahann sampai kulit jadi dibutuhkan beberapa tahapan proses tertentu yang menggunak agensia peminyakan, sehingga kandungan minyak/lemak kulit Oil-Pull-Up rela lebih tinggi, dan salah satu sifat Oil-Pull-Up tersebut apabila ditarik a menghasilkan efek dua warna yang kontras.

\section{MATERI DAN METODA}

\section{Materi}

Kulit Oil-Pull-Up sebanyak 9 lembar berasal dari perusahaan kulit PT. S Garama (Jawa Tengah), PT. Ecco (Jawa Timur), dan PT. Wira Sakti (DKI Jakart

Pengambilan sampel kulit dilakukan secara random dari gudang keti perusahaan kulit tersebut.

\section{Metoda}

Sampel sebanyak 9 lembar setelah sampai di Balai Besar Penelitian d Pengembangan Industri barang Kulit, Karet dan Plastik langsung di uji Laboratorium Uji Komoditi Kulit dan Sepatu (LUKKUS).

Jenis uji yang dikerjakan adalah :

- Uji fisis meliputi : tebal, penyamakan, ketahamam gosok cat tutup ( kering basah ), kekuatan tarik, kemuluran, penyerapan air ( 2 jam dan 24 jam), ketahan letup, kekuatan sobek, dan kekuatan jahit.

- Uji kimiawi meliputi : kadar air, kadar abu jumlah, kadar $\mathrm{Cr} 2 \mathrm{O} 3$, kadar minya lemak dan $\mathrm{pH}$

- Uji organoleptis meliputi : keadaan kulit, kelentingan dan flek darah

Analisa data dilakukan dengan cara menghitung rata-rata dan standar devia sehingga akan diperoleh angka range terendah dan tertinggi. Sebagai tolok uk untuk hasil yang dicantumkan dalam rumusan adalah SNI 06-0234-1989, Ku Boks. Pelaksanaan penyusunan rancangan Standar Nasional Indonesia dimul dengan penyusunan oleh team dan dibahas dalam Rapat Panitia Teknis yang dihadi oleh produsen, unsur pemerintah, dan konsumen yang diadakan di BBKK Kemudian hasil dari Rapat Panitia Teknis dibahas dalam Rapat Pra Konsensus yan dihadiri oleh produsen, unsur pemerintah, dan konsumen yang diadakan di Ba Besar Penelitian dan Pengembangan industri barang Kulit, Karet dan Plastik. Has dari Prakonsensus dibahas lagi dalam Rapat Konsensus yang diadakan di Jakar dengan pembahas yang terdiri dari produsen, Pemerintah dan konsumen. Hasil Rap Konsensus ini selanjutnya diterbitkan sebagai Standar Nasional Indonesia untu komoditi yang diusulkan.

\section{BAII GAN MIIIAHASAN}

Kaielialan kulif atasan sepatu berdasarkan SNI 0234-89, Kulit Boks, adalah

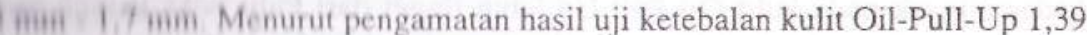

1,49 min. Demikian pula hasil uji parameter lainnya sesuai dengan SNI. Iif Heith, hehimega dipilih SNI. Kulit Boks sebagai acuan. Hal ini didukung (i1yahian Lahwa kulit Oil-Pull-Up tersebut menggunakan bahan baku kulit sapi

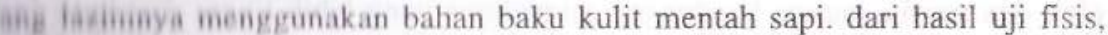
maniy, nigmoleptis, dan komparasinya dengan kulit boks peneliti merumuskan Iafii Hanilai kulii Oil-Pull-Up seperti yang tertera pada tabel 2 berikut ini.

Iahei I Humanan syarat mutu uji fisis, kimiawi, organoleptis dan komparasinya dengan SNI. Kulit Boks.

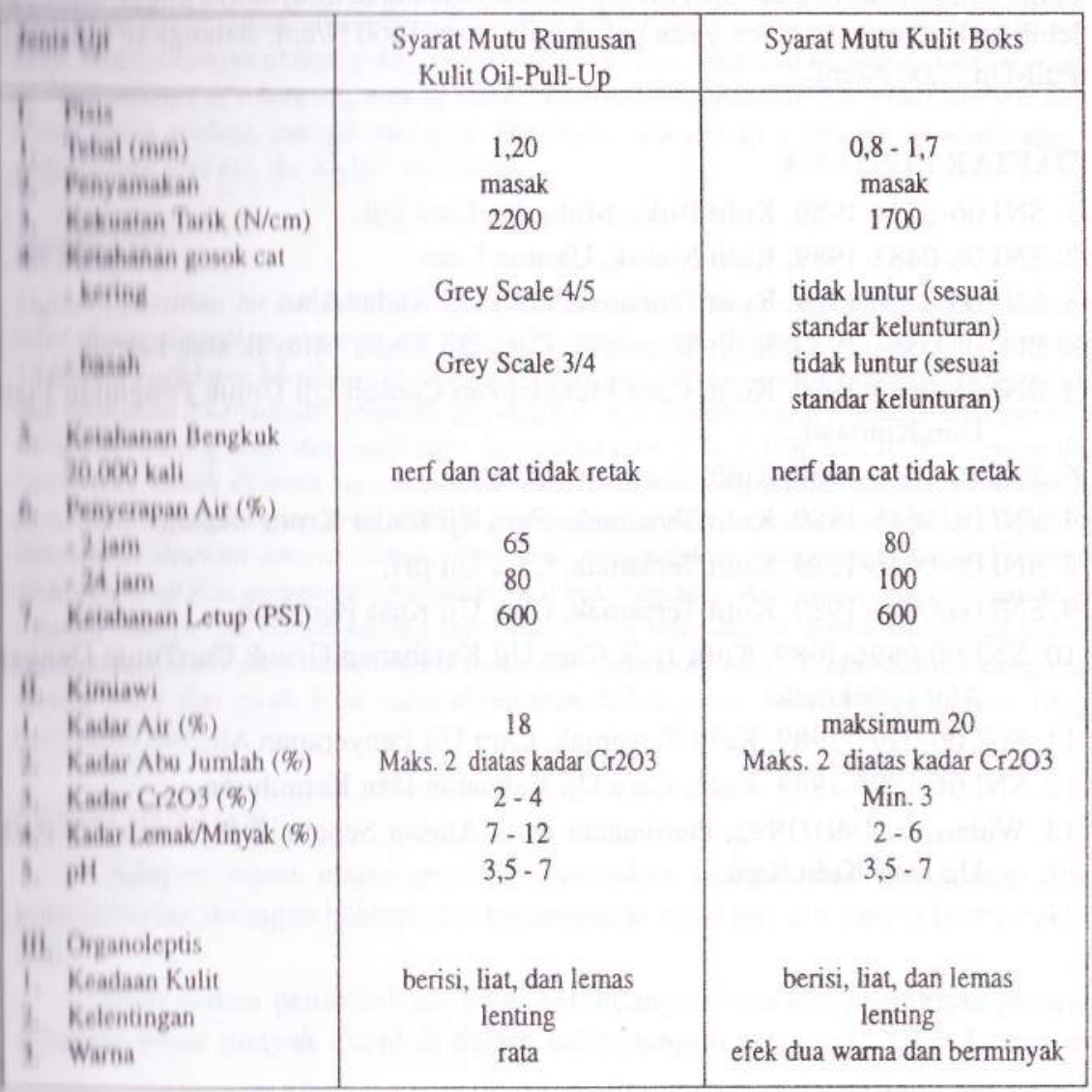


Untuk cara uji parameter-parameter pada rumusan yang tertera pada tabel menggunakan Standar Cara Uji yang ada pada SNI. Kulit boks. Hasil uji rata-rat kadar minyak pada kulit Oil-Pull-Up lebih tinggi dari kulit boks karena prose penyamakan kulit Oil-Pull-Up mengalami peminyakan dua kali.

Kulit Oil-Pull-Up mempunyai karakteristik tersendiri yaitu lebih taha terhadap air berpenampilan menarik yaitu bila ditarik/ditekan akan mempunya efek dua warna, karena kandungan minyaknya yang lebih tinggi dari kulit yan lain.

\section{KESIMPULAN}

Kulit Oil-Pull-Up lebih tahan air karena kadar minyak lebih tinggi dari kul boks. Kadar minyak kulit Oil-Pull-Up (7-12\%) dan kulit boks (2-6\%), sedangkal untuk kekuatan tarik kulit Oil-Pull-Up karena kandungan minyaknya tinggi, sehingg lebih besar dari kulit boks, yaitu untuk kulit boks $1660 \mathrm{~N} / \mathrm{cm}$, sedangkan kulit Oil Pull-Up $2200 \mathrm{~N} / \mathrm{cm}$.

\section{DAFTAR PUSTAKA}

1. SNI 06-0234-1989, Kulit Boks, Mutu dan Cara Uji.

2. SNI 06-0483-1989, Kulit Masak, Ukuran Luas

3. SNI 06-0563-1989, Kulit Tersamak, Cara Uji Kadar Abu.

4. SNI 06-0564-1989, Kulit Tersamak, Cara Uji Kadar Minyak atau Lemak.

5. SNI 06-0643-1989, Kulit, Cara Menyiapkan Contoh Uji Untuk Pengujian Fis Dan Kimiawi.

6. SNI 06-0644-1989, Kulit, Cara Uji Kadar Air.

7. SNI 06-0645-1989, Kulit Tersamak, Cara Uji Kadar Krom Oksida.

8. SNI 06-0646-1989, Kulit Tersamak, Cara Uji pH.

9. SNI 06-0995-1989, Kulit Tersamak, Cara Uji Kuat Bengkuk.

10. SNI 06-0996-1989, Kulit Jadi, Cara Uji Ketahanan Gosok Cat Tutup Deng Alat Crockmeter.

11. SNI 06-0997-1989, Kulit Tersamak, Cara Uji Penyerapan Air.

12. SNI 06-1795-1989, Kulit, Cara Uji Kekuatan Dan Kemuluran.

13. Widari, Ir. 1991/1992, Pembuatan Kulit Atasan Sepatu Type Finish Oil-Pul Up Dari Kulit Sapi. 